\title{
Handbook of Florida Water Regulation: Fish and Wildlife Conservation Commission ${ }^{1}$
}

\author{
Michael T. Olexa, Luke D'Isernia, Laura Minton, Dulcy Miller, and Sarah Corbett ${ }^{2}$
}

\section{Preface}

This handbook is designed to provide an accurate, current, and authoritative summary of the principle Federal and Florida laws that directly or indirectly relate to agriculture. This handbook should provide a basic overview of the many rights and responsibilities that farmers and farmland owners have under both Federal and Florida laws as well as the appropriate contact information to obtain more detailed information. However, the reader should be aware that because the laws, administrative rulings, and court decisions on which this handbook is based are subject to constant revision, portions of this publication could become outdated at anytime. Several details of cited laws are also left out due to space limitations.

This handbook is distributed with the understanding that the authors are not engaged in rendering legal or other professional advice, and the information contained herein should not be regarded as a substitute for professional advice. This handbook is not all inclusive in providing information to achieve compliance with the Federal and Florida laws and regulations governing water protection. For these reasons, the use of these materials by any person constitutes an agreement to hold harmless the authors, the Florida Cooperative Extension Service, the Institute of Food and Agricultural Sciences, and the University of Florida for any liability claims, damages, or expenses that may be incurred by any person as a result of reference to or reliance on the information contained in this handbook.

\section{Overview}

The Fish and Wildlife Conservation Commission (FWC) came into existence on July 1, 1999, with the approval of a constitutional amendment in the 1998 General Election (Article XII, Section 23, Florida Constitution). Under Article XII, Section 23, the State Legislature combined the Marine Fisheries Commission, the Game and Fresh Water Fish Commission, and elements of the Divisions of Marine Resources and Law Enforcement of the Florida Department of Environmental Protection to form the Fish and Wildlife Conservation

1. This is EDIS document FE595, a publication of the Food and Resource Economics Department, Florida Cooperative Extension Service, Institute of Food and Agricultural Sciences, University of Florida, Gainesville, FL. Published December 2005. Please visit the EDIS website at http://edis.ifas.ufl.edu.

2. Michael T. Olexa, Professor, Food and Resource Economics Department, Florida Cooperative Extension Service, Institute of Food and Agricultural Sciences, University of Florida, Gainesville, FL; Director, Agricultural Law Center, University of Florida, Gainesville, FL; and Chair, Agricultural Law Committee of The Florida Bar. Luke D'Isernia, former student (graduated cum laude in 2005), Levin College of Law, University of Florida, Gainesville, FL. Laura Minton, Attorney, Dean, Mead, Egerton, Bloodworth, Capouano, and Bozarth, Orlando, FL. Dulcy Miller, attorney, Foley and Lardner, LLP, Orlando, FL. Sarah Corbett, Attorney, Florida Second District Court of Appeal, Lakeland, FL.

The Institute of Food and Agricultural Sciences (IFAS) is an Equal Opportunity Institution authorized to provide research, educational information and other services only to individuals and institutions that function with non-discrimination with respect to race, creed, color, religion, age, disability, sex, sexual orientation, marital status, national origin, political opinions or affiliations. U.S. Department of Agriculture, Cooperative Extension Service, University of Florida, IFAS, Florida A. \& M. University Cooperative Extension Program, and Boards of County Commissioners Cooperating. Larry Arrington, Dean 
Commission. The purpose of this Commission is the management, protection, and conservation of wild animal life and fresh water aquatic life. Some of the agency's activities include:

- Habitat improvement.

- Research.

- Inspection of construction and development projects.

- Development of public recreational areas.

- Running a conservation information service program.

- Updating a list of threatened and endangered freshwater aquatic and land species.

- Regulating the hunting and fishing of Florida's wildlife through the issuing and enforcement of hunting and fishing licenses and various permits.

- Regulating the possession and exploitation of captive wildlife through permitting and licensing various activities, including alligator farms, freshwater fish farms, dealers and buyers of fish or frogs, and the sale and purchase of animal furs and hides.

The Florida Department of Environmental Protection (DEP) maintains a list of Florida marine species and the U.S. Department of Interior maintains a national list (see FE592, Endangered Species Act). The Endangered Species Act makes the killing, harassment, or destruction of these animals or their nests or eggs illegal.

Although FWC has jurisdiction over any fresh running waters of the state, the DEP is the agency primarily responsible for enforcement of water regulations. Jurisdictional directives in this area are overlapping, as many agencies have been granted the authority to address this concern.

\section{What Is the FWC's Structure?}

The Board of Commissioners is appointed by the Governor and confirmed by the State Senate to terms of five years. There are currently seven commissioners on the Board of Commissioners. The Executive Director, who serves at the pleasure of the commissioners, is generally responsible for the operation of the FWC, including the implementation of policies and rules made by the Board of Commissioners. The FWC is divided into six agency divisions: The Fish and Wildlife Research Institute, Freshwater Fisheries Management, Habitat and Species Conservation, Hunting and Game Management, Law Enforcement, and Marine Fisheries Management. The FWC is also divided into fourteen agency offices, including the Legislative Affairs Office, the Legal Office, Office of the Inspector General, and the Office of Strategy and Planning. Each of these agency offices and the Division of Fish and Wildlife Research Institute are under the direct supervision of the executive director.

\section{Acknowledgments}

The authors are indebted to the personnel of both state and federal agencies who provided their time and advice in the preparation of this handbook. The authors are especially indebted to Richard Budell of the Office of Agricultural Water Policy of the Florida Department of Agriculture and Consumer Services for providing funds for the development of this publication. 